\title{
Pengaruh Pengungkapan Corporate Social Responsibility Terhadap Abnormal Return
}

\author{
Megawati Cheng \\ Alumni Fakultas Ekonomi Universitas Kristen Petra Surabaya \\ Yulius Jogi Christiawan \\ Fakultas Ekonomi Universitas Kristen Petra Surabaya \\ Email: yulius@peter.petra.ac.id
}

\begin{abstract}
ABSTRAK
Penelitian ini bertujuan mengetahui pengaruh pengungkapan corporate social responsibility (CSR) terhadap abnormal return. Penelitian ini menggunakan variabel kontrol return on equity (ROE) dan price to book value (PBV). Pengukuran pengungkapan CSR didasarkan pada Global Reporting Initiative (GRI). Sedangkan, abnormal return dihitung dengan menggunakan market adjusted model. Penelitian dilakukan terhadap laporan tahunan 40 perusahaan sumber daya alam yang terdaftar di Bursa Efek Indonesia pada tahun 2007-2009. Hasil penelitian menunjukkan bahwa pengungkapan CSR berpengaruh signifikan terhadap abnormal return yang menandakan bahwa investor mempertimbangkan informasi CSR untuk membuat keputusan. Variabel kontrol ROE berpengaruh signifikan negatif terhadap abnormal return. Sedangkan, Variabel kontrol PBV tidak berpengaruh signifikan terhadap abnormal return.
\end{abstract}

Kata kunci: Pengungkapan corporate social responsibility, abnormal return, Return on Equity

\begin{abstract}
The purpose of this research was to study the significant effect of CSR disclosure on abnormal return. Meanwhile this study used return on equity (ROE) and price to book value $(P B V)$ as control variables. CSR disclosure is based on Global Reporting Initiative (GRI). This research used annual reports of 40 companies related to the natural resources listed in Indonesia Stock exchange in the period of 2007-2009. The results of this research concluded that CSR disclosure has significant effect on abnormal return which indicates that investor consider the CSR for making decision. ROE as control variable has negative relationship on abnormal return. Whereas, PBV has no significant effect on abnormal return.
\end{abstract}

Keywords: Corporate social responsibility disclosure, abnormal return, Return on Equity

\section{PENDAHULUAN}

Kajian corporate social responsibility (CSR) semakin berkembang pesat seiring banyak kasus yang terjadi dimana perusahaan tidak memberikan kontribusi positif secara langsung kepada masyarakat. Pentingnya CSR, telah mendapat perhatian pemerintah dan perusahaan yang ada di Indonesia. Undang-Undang No. 40 Tahun 2007 tentang Perseroan Terbatas (pasal 74 ayat 1a) mewajibkan perusahaan yang usahanya dibidang dan/atau berkaitan dengan sumber daya alam untuk melakukan CSR. CSR di Indonesia baru diwajibkan bagi perusahaan bidang tertentu saja terkait dengan semakin parahnya kerusakan lingkungan yang terjadi di Indonesia maupun dunia, mulai dari penggundulan hutan, polusi udara dan air, hingga perubahan iklim (Utama 2007).

Pengambil keputusan ekonomi saat ini, tidak hanya melihat kinerja keuangan entitas, karena kesimpulan baik atau buruknya kinerja entitas tidak cukup hanya dilihat dari besarnya laba yang dihasilkan. Penerapan CSR dipercaya dapat 
meningkatkan kinerja perusahaan, dimana para investor cenderung menanamkan modal kepada perusahaan yang melakukan kegiatan CSR. Karena perusahaan yang mengedepankan aspek sustantibility tentu akan mennerjemahkan prinsip sustantibility ke dalam strategi dan operasi perusahaan, sehingga faktor-faktor yang mendatangkan keuntungan bagi perusahaan dapat menjadi bahan masukan dalam rangka pengambilan keputusan oleh investor. Oleh karena itu, perusahaan-perusahaan dapat menggunakan informasi CSR sebagai salah satu keunggulan kompetitif perusahaan. Eipstein dan Freedman (1994) seperti yang dikutip Sayekti dan Ludovicus, (2007), menemukan bahwa investor individual tertarik terhadap informasi sosial yang dilaporkan dalam laporan tahunan, sehingga manajemen perusahaan saat ini tidak hanya dituntut terbatas atas pengelolaan dana yang diberikan, namun juga meliputi dampak yang ditimbulkan oleh perusahaan terhadap lingkungan alam dan sosial. Menurut Arya dan Zhang (2009) seperti yang dikutip Nuzula dan Kato (2010), upaya perusahaan untuk melakukan CSR bukanlah sesuatu yang sia-sia dan investor memberikan respon yang baik pada perusahaan-perusahaan tersebut. Survey global yang dilakukan oleh The Economist Intelligence Unit menunjukkan bahwa $85 \%$ eksekutif senior dan investor dari berbagai organisasi menjadikan CSR sebagai pertimbangan utama dalam pengambilan keputusan (Warta Ekonomi, Desember 2006).

Melihat tuntutan tersebut di atas, perusahaan-perusahaan publik di Indonesia yang membuat pelaporan CSR secara terpisah mengalami peningkatan sebanyak $21,11 \%$ pada tahun 2008 dibandingkan tahun sebelumnya (ISRA, 2010). Kelana dan Chandra Wijaya (2005) menyatakan bahwa aspek kepercayaan dari investor merupakan salah satu aspek yang sangat berpengaruh dalam pasar saham. Oleh sebab itu, suatu pengungkapan akan ditanggapi oleh investor dengan beragam. Pengungkapan CSR yang dilakukan perusahaan diharapkan mampu memberikan signal dan dapat meningkatkan nilai perusahaan dimata investor. Hal ini mengindikasikan bahwa perusahaan yang menerapkan CSR mengharapkan akan direspon positif oleh pelaku pasar sehingga dapat memaksimalkan profit dalam jangka panjang. Suatu informasi dapat dikatakan mempunyai nilai guna bagi investor apabila informasi tersebut memberikan reaksi untuk melakukan transaksi di pasar modal. Hal ini dapat dilihat dari abnormal return yang merupakan salah satu indikator yang dapat dipakai guna melihat keadaan pasar yang sedang terjadi (Jogiyanto 2009). Berdasarkan teori pasar yang efisien dikatakan bahwa informasi yang tersedia dipasar tercermin didalam harga pasar. Oleh karena itu, diharapkan investor mempertimbangkan informasi CSR yang diungkapkan dalam laporan tahunan perusahan. Apabila informasi CSR dipertimbangkan investor dalam pengambilan keputusan yang diikuti dengan kenaikan pembelian saham perusahaan sehingga terjadi kenaikan harga saham yang melebihi return yang diekpektasikan oleh investor sehingga pada akhirnya informasi CSR merupakan informasi yang memberikan nilai tambah bagi investor dan menyebabkan abnormal return.

Penelitian yang menguji pengaruh CSR sudah banyak dilakukan. Hasil penelitian Nuzula dan Kato (2010) pada perusahaan di Jepang menunjukan bahwa investor memberikan respon terhadap pengungkapan CSR perusahaan. Di Indonesia, penelitian Nurdin dan Cahyandito (2006) menunjukan bahwa pengungkapan tematema sosial dan lingkungan dalam laporan tahunan berpengaruh signifikan terhadap reaksi investor yang diukur dengan abnormal return dan volume perdagangan saham. Hal ini konsisten dengan Sayekti dan Ludovicus (2007) yang menyimpulkan bahwa pelaksanaan CSR memiliki dampak positif dan signifikan terhadap reaksi pasar. Namun demikian, pada penelitian-penelitian lain telah menunjukan hasil yang tidak konsisten. Diantaranya adalah penelitian Lorraine (2004), Dahlia dan Veronica (2008), dimana pengungkapan CSR tidak berpengaruh terhadap reaksi pasar.

Penelitian ini berbeda dengan penelitianpenelitian sebelumnya yang menggunakan sampel dari semua industri. Penelitian ini menggunakan perusahaan-perusahaan yang berhubungan dengan sumber daya alam mengingat Undang-Undang No. 40 Tahun 2007 tentang Perseroan Terbatas (pasal 74 ayat 1a) mewajibkan perusahaan yang kegiatan usahanya dibidang dan/atau berkaitan dengan sumber daya alam untuk melakukan CSR. Selain itu, menurut Hackston dan Milne (1996) dalam Suwardi et al. (2010) mengatakan bahwa perusahaan yang mempunyai tingkat sensitivitas yang tinggi terhadap lingkungan (rawan lingkungan) termasuk dalam tipe industri high profile. Perusahaan yang memiliki risiko politis yang tinggi (high profile) dan dengan kepemilikan manajemen yang besar cenderung mengungkapkan informasi sosial yang lebih banyak (Anggraeni 2006). Perusahaan ini pada umumnya merupakan perusahaan yang memperoleh sorotan masyarakat karena aktivitas operasinya memiliki potensi untuk bersinggungan dengan kepentingan luas. Berdasarkan pertimbangan-pertimbangan tersebut di atas maka penelitian ini ingin mengetahui 
apakah pengungkapan informasi CSR perusahaan yang berhubungan dengan sumber daya alam berpengaruh terhadap abnormal return.

Penelitian ini menggunakan perusahaanperusahaan yang terdaftar di Bursa Efek Indonesia pada tahun 2007-2009 dalam sektor industri yang berhubungan dengan sumber daya alam. Hal ini dikarenakan pemerintah telah menetapkan peraturan bahwa industri tersebut wajib menerapkan CSR sejak tahun 2007. Industri yang verhubungan dengan sumber daya alam berdasarkan program Peningkatan Kinerja Lingkungan Hidup (PROPER) diantaranya adalah: Sektor Agriculture, Sektor Pertambangan dan Sektor Industri Dasar dan Kimia

\section{PENGUNGKAPAN CORPORATE SOCIAL RESPONSIBILITY (CSR)}

Menurut World Business Council for Sustainable Development menjelaskan CSR merupakan suatu komitmen berkelanjutan oleh dunia usaha untuk bertindak secara etis dan memberikan kontribusi kepada pengembangan ekonomi dari komunitas setempat ataupun masyarakat secara luas, bersamaan dengan peningkatan taraf hidup pekerjanya beserta seluruh keluarganya. Sedangkan, menurut ISO 26000 mengenai pedoman tanggung jawab sosial yang segera akan diresmikan November 2011, CSR adalah Tanggung jawab sebuah organisasi terhadap dampakdampak dari keputusan-keputusan dan kegiatankegiatannya pada masyarakat dan lingkungan yang diwujudkan dalam bentuk perilaku transparan dan etis yang sejalan dengan pembangunan berkelanjutan dan kesejahteraan masyarakat; mempertimbangkan harapan pemangku kepentingan, sejalan dengan hukum yang ditetapkan dan norma-norma perilaku internasional; serta terintegrasi dengan organisasi secara menyeluruh. Perusahaan selain berorientasi terhadap laba, perusahaan juga bertanggungjawab terhadap masalah sosial yang ditimbulkan oleh aktivitas operasional yang dilakukan perusahaan dengan manajemen lingkungan sehingga tidak hanya terbatas pada orientasi kinerja keuangan perusahaan. Banyak manfaat yang dapat diperoleh atas aktivitas CSR antara lain: meningkatkan penjualan dan market share, memperkuat brand positioning, meningkatkan citra perusahaan, menurunkan biaya operasi, dan meningkatkan daya tarik perusahaan di mata para investor dan analisis keuangan. Dengan menjalankan tanggung jawab sosial, perusahaan diharapkan tidak hanya mengejar keuntungan jangka pendek, namun juga turut memberikan kontribusi bagi peningkatan kesejahteraan dan kualitas hidup masyarakat serta lingkungan sekitar dalam jangka panjang. Dengan melaksanakan CSR secara konsisten dalam jangka panjang akan menumbuhkan rasa keberterimaan masyarakat terhadap kehadiran perusahaan.

Pengungkapan CSR merupakan bagian dari akuntansi pertanggung jawaban sosial yang mengkomunikasikan informasi sosial kepada stakeholder. Menurut Guthrie dan Parker (1990) sebagaimana dikutip oleh Sayekti dan Ludovicus (2007), pengungkapan informasi CSR dalam laporan tahunan merupakan salah satu cara perusahaan untuk membangun, mempertahankan, dan melegitimasi kontribusi perusahaan dari sisi ekonomis dan politis. Selain itu juga, akuntansi pertanggungjawaban sosial dapat memberikan informasi mengenai sejauh mana organisasi atau perusahaan memberikan kontribusi positif maupun negatif terhadap kualitas hidup manusia dan lingkungannya.

Tanggungjawab sosial perusahaan bersifat wajib (mandatory) bagi kriteria perusahaan tertentu seperti yang disebutkan dalam UU No. 40 Tahun 2007 tentang Perseroan Terbatas pasal 74 menyatakan bahwa: Perseroan yang menjalankan usahanya dibidang dan atau berkaitan dengan sumber daya alam wajib melaksanakan tanggungjawab sosial dan lingkungan. Dan Tanggungjawab sosial dan lingkungan tersebut merupakan kewajiban perseroan yang dianggarkan dan diperhitungkan sebagai biaya perseroan yang pelaksanaanya dilakukan dengan memperhatikan kepatuhan dan kewajaran. Jika Perseroan yang tidak melaksanakan kewajiban tanggung jawab sosial akan dikenai sanksi sesuai dengan ketentuan peraturan perundangundangan.

Selain perusahaan wajib melakukan kegiatan CSR, UU No. 40 Tahun 2007 pasal 66 ayat (2) tentang Perseroan Terbatas juga mewajibkan perusahaan untuk mengungkapkan aktivitas tanggung jawab sosialnya dalam laporan tahunan. Namun demikian, item-item CSR yang diungkapkan perusahaan merupakan informasi yang masih bersifat sukarela (voluntary).

Konsep pelaporan CSR yang digagas oleh GRI adalah konsep sustainability report yang muncul sebagai akibat adanya konsep sustainability development. Dalam sustainability report digunakan metode triple bottom line, yang tidak hanya melaporan sesuatu yang diukur dari sudut pandang ekonomi saja, melainkan dari sudut pandang ekonomi, sosial dan lingkungan. Gagasan ini merupakan akibat dari adanya 3 dampak operasi perusahaan yaitu ekonomi, sosial dan lingkungan. GRI Guidelines menyebutkan bahwa, perusahaan harus menjelaskan dampak aktivitas 
perusahaan terhadap ekonomi, lingkungan dan sosial pada bagian standard disclosures. Yang kemudian ketiga dimensi tersebut diperluas menjadi 6 dimensi, yaitu: ekonomi, lingkungan, praktek tenaga kerja, hak asasi manusia, masyarakat, dan tanggungjawab produk.

\section{ABNORMAL RETURN}

Abnormal return merupakan salah satu indikator yang dapat dipakai guna melihat keadaan pasar yang sedang terjadi. Suatu informasi dapat dikatakan mempunyai nilai guna bagi investor apabila informasi tersebut memberikan reaksi untuk melakukan transaksi di pasar modal (Jogiyanto, 2009). Aspek kepercayaan (belief) dari investor merupakan salah satu aspek yang sangat berpengaruh dalam pasar saham. Oleh sebab itu, suatu announcement/disclosure akan ditanggapi oleh investor dengan beragam.

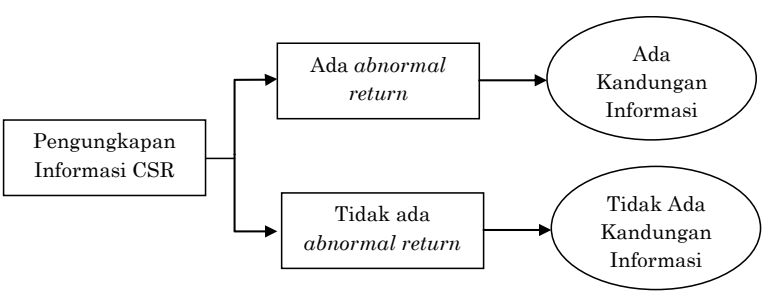

Sumber: Jogiyanto (2009)

\section{Gambar 1. Kandungan Informasi}

Jogiyanto (2009) mendefinisikan abnormal return sebagai selisih antara actual return dan expected return. Abnormal return akan positif jika return yang didapatkan lebih besar dari return yang diharapkan atau return yang dihitung. Sedangkan abnormal return akan negatif jika return yang didapat lebih kecil dari return yang diharapkan atau return yang dihitung. Studi peristiwa menganalisis abnormal return dari sekuritas yang mungkin terjadi di sekitar pengumuman dari suatu peristiwa. Actual Return atau return sesungguhnya yang terjadi pada waktu ke-t, merupakan selisih harga sekarang relative terhadap harga sebelumnya. Expected return merupakan return estimasi yang diharapkan oleh investor, yang ditentukan dengan model estimasi. Sebelum menentukan model untuk mengestimasi expected return, perlu ditentukan beberapa istilah periode sebagai dasar estimasi expected return, periode-periode tersebut adalah:

Periode estimasi (estimation period), umumnya merupakan periode sebelum peristiwa (event period). Pada gambar 2 periode estimasi ditunjukan dari t3 sampai dengan t4. Jogiyanto (2010) mengatakan bahwa tidak ada patokan untuk menentukan lamanya panjang periode estimasi ini. Panjang periode estimasi yang umum digunakan adalah berkisar dari 100 hari sampai dengan 250 hari untuk data harian.

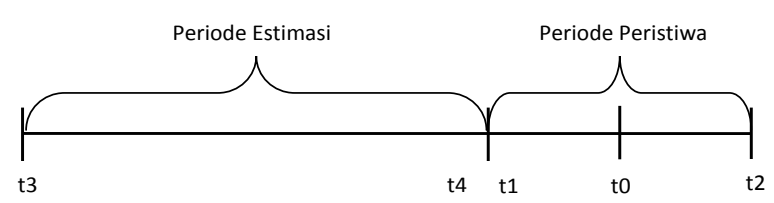

Sumber: Jogiyanto, 2010

Gambar 2. Periode Estimasi dan Periode Peristiwa

Periode peristiwa (event period) atau jendela peristiwa (event window) merupakan periode terjadinya peristiwa dan pengaruhnya. Dimana pada gambar 2 terjadinya peristiwa ditunjukan dengan t0 sehingga yang dinamakan dengan periode peristiwa adalah periode jendela dari t1 sampai dengan t2. Lamanya periode jendela tergantung jenis peristiwanya. Jika peristiwanya merupakan peristiwa yang nilai ekonomisnya dapat ditentukan dengan mudah oleh investor, periode jendela dapat pendek, disebabkan oleh investor yang dapat bereaksi dengan cepat. Sebaliknya, untuk peristiwa yang nilai ekonomisnya sulit ditentukan oelh investor, investor akan membutuhkan waktu yang lama untuk bereaksi. Umumnya periode jendela juga melibatkan hari sebelum tanggal peristiwa untuk mengetahui apakah terjadi kebocoran informasi, yaitu apakah pasar sudah mendengar informasinya sebelum informasi itu sendiri diumumkan (Jogiyanto, 2010).

Return ekspektasi dapat dihitung menggunakan 3 model estimasi tanpa sesuaian resiko yaitu (Jogiyanto, 2010): (1) Mean Adjusted Return, (2) Market Model Return, (3) Market Model Return dan model estimasi dengan sesuaian risiko. Pada model Mean Adjusted Return, expected return bernilai konstan sama dengan rata-rata return realisasi sebelumnya selama periode estimasi. Model ini menganggap jika suatu pasar efisien dan return saham berbeda-beda secara random di seputar nilai sebenarnya. Perhitungan expected return dengan model pasar (market model) dilakukan dengan dua tahap, yaitu: (1) membentuk model ekspektasi dengan menggunakan data realisasi selama periode estimasi dan (2) menggunakan model ekspektasian ini untuk mengestimasi expected return di periode jendela. Model Market Adjusted Return menganggap bahwa praduga yang terbaik untuk mengestimasi return saham adalah return indeks pasar pada saat tersebut. Dengan menggunakan model ini, maka tidak perlu menggunaka periode estimasi untuk memberntuk model estimasinya, karena 
return saham yang diestimasi adalah sama dengan return indeks pasar. Return ekspektasi dengan sesuaian resiko diantaranya yaitu Capital Asset Pricing Model (CAPM). CAPM mempertimbangkan resiko pasar untuk menyesuaikan return ekspektasinya. Resiko yang digunakan di CAPM adalah resiko pasar atau resiko sistemik yang diukur dengan beta. Model CAPM adalah sebagai berikut: $\mathrm{E}(\mathrm{Ri})=\mathrm{Rf}+B(\mathrm{Rm}-\mathrm{Rf})$, dimana $\mathrm{Rf}$ adalah tingkat bunga bebas risiko (risk free rate) yang dalam hal ini digunakan rata-rata suku bunga Sertifikat Bank Indonesia (SBI). Rm adalah return pasar yang biasanya menggunakan Indeks Harga Saham Gabungan (IHSG), dan $B$ adah beta masing-masing saham. Return estimasian tidak diperlukan lagi apabila menggunakan CAPM.

\section{Hubungan Pengungkapan Informasi CSR dalam Laporan Tahunan dan Abnormal Return}

Sebagai salah satu bentuk tanggung jawab perusahaan terhadap masyarakat dan para stakeholders lainnya, perusahaan seringkali terlibat dalam kegiatan-kegiatan CSR. Para stakeholders dapat memberikan apresiasi yang lebih bagi perusahaan-perusahaan yang terlibat dalam kegiatan CSR. Hal ini sejalan dengan signaling theory dimana perusahaan dapat meningkatkan nilai perusahaan melalui pelaporannya dengan mengirimkan signal melalui laporan tahunannya. Pengungkapan aktivitas perusahaan yang berkaitan dengan CSR merupakan salah satu cara untuk mengirimkan signal positif kepada stakeholders dan pasar mengenai prospek perusahaan di masa yang akan datang bahwa perusahaan memberikan guarantee atas keberlangsungan hidup perusahaan dimasa yang akan datang. Pengungkapan CSR dapat mengirimkan signal promosi atau informasi lain yang menyatakan bahwa perusahaan tersebut lebih baik daripada perusahaan lain karena peduli dengan dampak ekonomi, lingkungan dan sosial dari aktivitas perusahaan.

Pengungkapan CSR diharapkan memiliki kandungan informasi, sehingga pasar atau investor akan bereaksi setelah pengumuman itu diterima. Signal positif ini diharapkan dapat menghasilkan respon positif dari pasar. Reaksi investor menurut Jogiyanto (2009) dapat diukur dengan menggunakan abnormal return. Adapun reaksi investor beragam atas sebuah informasi. Informasi yang memberikan keyakinan atas prospek perusahaan yang bagus di masa yang akan datang akan direspon dengan peningkatan harga saham. Dengan demikian, dapat disimpulkan bahwa pengungkapan informasi CSR dalam laporan tahunan perusahaan berpengaruh terhadap abnormal return.

Penelitian yang mendukung adanya hubungan antara CSR dengan abnormal return adalah penelitian Nurdin dan Cahyandito (2006) yang menunjukkan bahwa aktivitas CSR berpengaruh positif terhadap abnormal return. Hasil penelitian ini konsisten dengan penelitian Almilia dan Wijayanto (2007) yang dikutip Dahlia dan Veronica, (2008) dan Brammer (2005), perusahaan yang memiliki kinerja lingkungan (environmental performance) yang bagus akan direspon positif oleh para investor melalui fluktuasi harga saham yang semakin naik dari periode ke periode dan sebaliknya jika perusahaan memiliki kinerja lingkungan (environmental performance) yang buruk maka akan muncul keraguan dari para investor terhadap perusahaan tersebut dan direspon negatif dengan fluktuasi harga saham perusahaan di pasar yang semakin menurun dari tahun ke tahun. Penelitian Frooman (1997) yang dikutip oleh Colwell (2010) juga menyatakan bahwa perusahaan dengan kinerja lingkunagn yang buruk akan menurunkan kekayaan (wealth) pemegang saham. Berdasarkan uraian di atas, maka hipotesis yang dapat dirumuskan adalah:

$\mathrm{H}_{1}$ : Pengungkapan informasi CSR berpengaruh positif signifikan terhadap Reaksi Investor (abnormal return)

\section{Hubungan Return on Equity (ROE) terhadap Abnormal Return}

Salah satu analisa rasio yang sering digunakan oleh investor adalah rasio profitabilitas perusahaan. Return on Equity (ROE) adalah salah satu rasio profitabilitas yang membandingkan laba bersih (net income) dengan total stokholder's equity perusahaan. Menurut Gitman (2006), ROE adalah setiap dollar dari net income yang dihasilkan perusahaan dari setiap dollar yang diinvestasikan oleh investor. ROE menunjukan kemampuan perusahaan untuk menghasilkan laba bersih. Investor selalu berharap untuk mendapatkan ROE yang tinggi, akan tetapi harapan investor ini tidak selalu sesuai dengan kenyataannya karena adanya faktor resiko. ROE yang tidak terduga atau tidak sesuai dengan ekspektasi dari investor dapat membuat pasar bereaksi yang ditunjukan dengan adanya abnormal return. Perubahan ROE perusahaan akan mengakibatkan perubahan nilai perusahaan sehingga hal ini akan menimbulkan reaksi dari invetor yang tercermin pada abnormal return. Semakin tinggi ROE perusahaan dianggap sebagai kabar baik (good news) karena ROE yang besar berarti semakin besar peluang para investor untuk memperoleh laba bersih dari setiap modal 
yang diinvestasikan sehingga akan direspon positif oleh pasar yang tercermin dalam abnormal return. Sebaliknya, semakin rendah ROE perusahaan dianggap sebagai (bad news) karena ROE yang rendah berarti semakin kecil peluang pemilik perusahaan memperoleh keuntungan dari laba bersih untuk setiap modal yang diinvestasikan sehingga akan direspon negatif oleh pasar. Hal ini didukung dengan penelitian Mulyono (2008) yang menemukan variable ROE berpengaruh terhadap abnormal return. Sehingga dapat dibuat hipotesa:

$\mathrm{H}_{2}$ : ROE berpengaruh positif signifikan terhadap abnormal return.

\section{Hubungan Price to Book Value (PBV) ter- hadap Abnormal return}

Price to Book Value atau biasa dikenal juga dengan istilah market to book value. Perusahaan dengan PBV yang tinggi memungkinkan perusahaan mendapatkan atau menambah laba sehingga PBV perusahaan merupakan hal yang perlu dipertimbangkan oleh investor (Scott, 2003). Investor tetap harus berhadapan dengan resiko sehingga ekspektasi investor terhadap perusahaan dapat saja berbeda dengan kinerja perusahaan yang sesungguhnya. Kenaikan atau penurunan PBV perusahaan memiliki kandungan informasi yang akan menimbulkan reaksi investor yang ditunjukan dengan abnormal return. PBV perusahaan yang tinggi menandakan bahwa perusahaan memiliki kemampuan untuk mempunyai kinerja yang baik dalam arti mampu meningkatkan laba, meningkatkan harga saham atau menghasilkan produk yang berhasil sehingga hal ini akan direspon positif oleh invetor. Sedangkan, PBV perusahaan yang rendah menandakan perusahaan memiliki pertumbuhan yang rendah sehingga hal ini akan direspon negatif oleh pasar. Penjelasan ini didukung dengan hasil penelitian terdahulu yang dilakukan oleh Dahlia dan Veronica (2008) yang menemukan hubungan yang positif antara PBV dan abnormal return sehingga hipotesis dalam penelitian ini adalah:

$\mathrm{H}_{3}$ : PBV berpengaruh positif signifikan terhadap abnormal return.

\section{METODE PENELITIAN}

Model analisis yang digunakan untuk menguji hipotesis dalam penelitian ini adalah analisis regresi berganda, sebagai berikut:

$$
\mathrm{CAR}=B_{0}+B_{1} \mathrm{CSRI}+B_{2} \mathrm{ROE}+B_{3} \mathrm{PBV}+\varepsilon
$$

Keterangan:

CAR : cummulative Abnormal Return harian perusahaan
$B_{0} \quad$ : konstanta persamaan regresi

$B_{1,2,3} \quad$ : koefisien regresi pada setiap variabel

CSRI : corporate Social Disclosure Index

ROE : return on Equity Ratio

PBV : price to book value

$\mathcal{\varepsilon} \quad:$ error term

Jika informasi CSR memperngaruhi CAR, maka diprediksi koefisien CSRI dalam uji T akan signifikan dan bertanda positif. Sedangkan untuk melihat pengaruh variable control (PBV, ROE) terhadap CAR, maka berturut-turut dilihat dari signifikansi dan arah dari koefisien pada model.

Variable dependen dalam penelitian ini adalah Cumulative Abnormal Return (CAR). CAR merupakan akumulasi dari abnormal return yang merupakan selisih dari actual return dan expected return. Expected return dihitung dengan menggunakan market adjusted model. Periode jendela yang digunakan adalah 61 hari melibatkan 30 hari sesudah dan sebelum publikasi dan 1 hari pada saat dipublikasikannya annual report masingmasing perusahaan seperti terlihat pada gambar 3. Periode 30 hari dipilih karena sinyal berupa pengungkapan informasi CSR yang diberikan manajemen adalah sinyal yang sangat susah diukur nilai ekonomisnya sehingga investor membutuhkan waktu yang lebih lama untuk bereaksi.

Perhitungan CAR untuk masing-masing perusahaan merupakan akumulasi dari abnormal return selama periode 61 hari periode jendela dari t1 sampai dengan t2. Data yang digunakan dalam perhitungan abnormal return adalah data tanggal publikasi laporan tahunan, harga pasar saham untuk serta jumlah saham beredar. Langkahlangkah menghitung abnormal return untuk masing-masing perusahaan adalah sebagai berikut: 1) menentukan tanggal publikasi laporan tahunan perusahaan tahun 2007-2009, 2) menentukan periode peristiwa yaitu 30 hari sebelum dan setelah publikasi laporan tahunan, 3) menentukan expected return harian masing-masing perusahaan selama periode tahun 2008-2010 untuk 61 hari pengamatan. Perhitungan expected return dengan menggunakan market adjusted model yaitu menggunakan indeks harga saham harian untuk setiap sektor industri. Hal ini dilakukan dengan cara: (1) menentukan bobot market capitalization perusahaan dengan cara membagi market capitalization perusahaan dengan market capitalization keseluruhan perusahaan pada sektor yang sama. Market capitalization dihitung dengan mengalikan harga saham dengan jumlah saham yang beredar pada saat itu, (2) menentukan return perusahaan, (3) menentukan expected return dengan mengalikan 
bobot market capitalization dengan return perusahaan, 4) menentukan actual return harian masing-masing perusahaan selama periode tahun 2008-2010 untuk 61 hari pengamatan, 5) Menentukan abnormal return harian masingmasing perusahaan dengan mengurangkan nilai actual return dengan expected return, 6) Menjumlahkan abnormal return yang didapatkan selama 61 hari tersebut.

Variabel independen dalam penelitian ini adalah indeks pengungkapan CSR (CSRI) yang sesuai dengan konsep sustainability report yang digagas oleh Global Reporting Initiative (GRI). Penelitian ini menggunakan GRI sebagai indikator pengungkapan CSR berdasarkan penelitian terdahulu yang dilakukan oleh Dahlia dan Veronica (2008). Jumlah item komponen CSR perusahaan didapatkan dengan memberikan nilai 1 pada perusahaan yang mengungkapkan komponen CSR yang telah ditetapkan, bila tidak diberi angka 0 . Jumlah item komponen CSR yang diungkapkan perusahaan dibagi total komponen yang ditetapkan sebelumnya merupakan CSRI, sehingga CSRI masing-masing perusahaan merupakan persentase dari total skor item pengungkapan.

Variabel kontrol yang digunakan dalam penelitian ini adalah Price to Book Value (PBV) ratio dan Return on Equity (ROE). Penentuan ROE dilakukan dengan membagi laba bersih perusahaan dengan total ekuitas perusahaan, sedangkan PBV ditentukan dengan membagi harga pasar perusahaan dengan nilai buku perusahaan.

Jenis data yang digunakan dalam penelitian ini adalah data sekunder berupa laporan tahunan perusahaan yang berhubungan dengan sumber daya alam diperoleh dari situs Bursa Efek Indonesia (BEI) atau website perusahaan, tanggal publikasi laporan tahunan yang diperoleh dari situs Bapepam, data harga saham perusahaan, data Indeks Harga Saham Gabungan (IHSG) yang diperoleh dari laboratorium pasar modal Universitas Kristen Petra, dan volume perdagangan saham yang diperoleh dari Indonesian Capital Market Directory (ICMD)

Karakteristik dan batasan populasi untuk mengumpulkan data yang diperlukan dalam penelitian ini adalah semua perusahaan yang berhubungan dengan sumber daya alam yang terdaftar di Bursa Efek Indonesia. Industri yang berhubungan dengan sumber daya alam berdasarkan program Peningkatan Kinerja Lingkungan Hidup (PROPER) diantaranya adalah: 1) sektor Perkebunan (Agroindustri), 2) sektor Pertambangan terdiri dari: Pertambangan batu bara, Pertambangan Minyak dan Gas Bumi, Pertambangan Logan dan Mineral lainnya dan 3) sektor Industri Dasar dan Kimia terdiri dari: Semen, Logam dan sejenisnya, Kayu dan pengolahannya, Pulp dan Kertas, Farmasi, Tekstil dan Garment

Penarikan sampel menggunakan cara Purposive Sampling, artinya bahwa penentuan sampel mempertimbangkan kriteria-kriteria tertentu yang telah dibuat terhadap obyek yang sesuai dengan tujuan penelitian. Dari keseluruhan populasi, tidak semuanya diteliti. Pengambilan sampel dibatasi dengan persyaratan sebagai berikut: terdaftar di Bursa Efek Indonesia pada tahun 2007-2009, mempublikasikan laporan tahunan tahun 2007-2009, mengungkapkan informasi CSR dalam laporan tahunan, tidak delisting selama periode peristiwa, harga saham perusahaan tersedia dengan lengkap. Analisis data dimulai dengan menyusun statistika deskriptif, melakukan perhitungan variable bebas, meregresikan variabel bebas terhadap variabel terikat, kemudian melakukan uji asumsi klasik, dan dilakukan uji hipotesis serta pembahasan hasil penelitian.

\section{HASIL PENELITIAN DAN PEMBAHASAN}

Penelitian dilakukan terhadap 116 laporan tahunan 40 perusahaan, yang merupakan hasil pemilihan dari perusahaan-perusahaan yang berhubungan dengan sumber daya alam yang terdaftar di Bursa Efek Indonesia berdasarkan kriteria-kriteria yang telah ditetapkan dari tahun 2007 sampai dengan 2009. Empat puluh perusahaan tersebut terdiri dari: 10 perusahaan industri agrobisnis, 11 perusahaan pertambangan dan 20 perusahaan kimia dasar.

\section{Tabel 1. Hasil Statistik Deskriptif}

\begin{tabular}{l|r|r|r|r|r}
\multicolumn{7}{|c}{ Des criptive Statis tics } \\
\hline & \multicolumn{1}{|c|}{$\mathrm{N}$} & \multicolumn{1}{c}{ Minimum } & Maximum & \multicolumn{1}{c}{ Mean } & Std. Deviation \\
\hline CAR & 116 & -1.32 & 3.78 & .3189 & .65237 \\
CSRI & 116 & .1333 & .6222 & .418769 & .1094038 \\
ROE & 116 & -99.3200 & 84.6000 & 16.051897 & 21.4013681 \\
PBV & 116 & -.3300 & 11.7400 & 2.828534 & 2.8221713 \\
Valid N (listw ise) & 116 & & & & \\
\hline
\end{tabular}

Dari diskriptif data diketahui bahwa CAR menunjukan tren yang mengalami peningkatan pada tahun 2008-2010. Terlihat bahwa pada tahun 2008-2009 CAR mengalami peningkatan namun pada tahun 2010 mengalami sedikit penurunan karena $75 \%$ perusahaan memiliki CAR yang lebih rendah dibandingkan tahun sebelumnya. CAR pada tahun 2008, menunjukan reaksi investor untuk laporan tahunan 2007, Perusahaan PT Tambang Batu Bara Tbk merupakan perusahaan yang paling mendapat respon pasar positif. Hal ini terlihat dari CAR yang dihasilkan oleh perusahaan ini merupakan yang tertinggi. Sedang- 
kan, perusahaan yang mendapat respon pasar negatif yaitu ditunjukan dengan CAR yang negatif adalah PT Polysindo Eka Perkasa Tbk. Pada tahun 2009, perusahaan yang memperlihatkan CAR tertinggi adalah PT Energi Mega Perkasa, sedangkan CAR terendah adalah PT Citra Tubindo. Pada tahun 2010, CAR tertinggi diperoleh dari perusahaan PT Bayan Resources Tbk, sedangkan yang terendah diperoleh dari perusahaan PT Bisi Internasional Tbk. Telihat bahwa perusahaan-perusahaan dari sektor pertambangan (mining) yang paling banyak mendapatkan respon positif dari investor. Hal ini ditunjukan dari CAR tertinggi dari tahun 2008-2010, berasal dari sektor pertambangan.

CSRI perusahaan yang berhubungan dengan sumber daya alam menunjukan kecenderungan tren yang positif yaitu mengalami kenaikan sejak tahun 2007 hingga tahun 2009. Hal ini mengindikasikan bahwa perusahaan semakin memberi perhatian pada aktivitas CSR dan mengungkapkannya dalam laporan tahunannya. CSRI tertinggi pada tahun 2007 adalah perusahaan Medco Energi Tbk. Kemudian pada tahun 2008, sebagian besar perusahaan mengalami peningkatan, perusahaan yang mengalami peningkatan signifikan diantaranya adalah PT Citra Tubindo Tbk, PT Kimia Farma Tbk, dan PT Unggul Indah Tbk. Pada tahun 2009, CSRI juga mengalami peningkatan namun tidak sesignifikan tahun sebelumnya karena terdapat beberapa mengalami penurunan CSRI dibandikan dengan tahun sebelumnya diantaranya adalah Indotambang Raya Megah Tbk, Medco Energi Tbk, dan Tambang Batu Bara Bukit Asam Tbk.

Selama periode 2007 hingga 2009, return on equity (ROE) dari perusahaan yang berhubungan dengan sumber daya alam mengalami tren yang cukup stabil. Rata-rata ROE setiap tahun adalah sebesar $15,94 \%$ pada tahun $2007,15,34 \%$ pada tahun 2008, dan 14,14\% pada tahun 2009. Hal ini menunjukan pada tahun 2008, ROE perusahaan cenderung stabil apabila dibandingkan dengan tahun sebelumnya. Meskipun pada tahun 2008, terdapat beberapa perusahaan yang mengalami penurunan ROE dibandingkan dengan tahun sebelumnya, namun sebagian besar perusahaanperusahaan mengalami kenaikan ROE. Dimana kenaikan paling signifikan terjadi pada perusahaan Medco Energi Internasional Tbk (Dari $1.27 \%$ menjadi $38.22 \%$ ). Pada tahun 2009, perusahaan mengalami sedikit penurunan dibandingkan tahun sebelumnya. Perusahaan yang memiliki rata-rata ROE terendah dari tahun 20072009 adalah PT Multibreeder Adiwarma Indonesia Tbk. Sedangkan perusahaan yang memiliki ROE tertinggi dari tahun 2007-2009 adalah PT Tambang Batu Bara Bukit Asam Tbk.

Rata-rata PBV dari tahun 2007-2009 berturut-turut adalah 3,82 kali, 1,69 kali, dan 2,61 kali. Perusahan yang mengalami rata-rata pertumbuhan tertinggi selama periode tersebut adalah PT Perusahaan Gas Negara Tbk. Sedangkan, perusahaan yang memiliki rata-rata pertumbuhan terendah selama periode tersebut adalah PT Asia Pasific Fibers Tbk. Secara keseluruhan, pertumbuhan perusahaan mengalami tren yang negatif. Penurunan yang signifykan (sebesar -62,1\%) terjadi pada tahun 2008 yang dipengaruhi oleh rata-rata perusahaan yang berhubungan dengan sumber daya alam terkena dampak dari krisis global yang mengakibatkan nilai pasar dari perusahaan-perusahaan yang berhubungan dengan sumber daya alam ini mengalami penurunan drastis. Namun pada tahun 2009, persepsi pasar sudah cenderung membaik dan meningkatkan PBV perusahaan.

Sebelum melakukan pengujian hipotesis dengan regresi berganda, dilakukan pengujian terhadap empat asumsi klasik terlebih dahulu, yaitu: uji autokorelasi, multikolinearitas, heterokedastisitas, dan normalitas. Pengujian asumsi klasik autokorelasi dilakukan dengan DurbinWatson dan diperoleh angka 1,653. Angka ini memenuhi kriteria DW terletak antara 2 dan -2. Dengan demikian dapat disimpulkan tidak terjadi autokorelasi. Pengujian asumsi klasik multikolinearitas menunjukan bahwa tidak terdapat data dengan nilai VIF di atas 10, dan tolerance value dibawah 0,1. Uji heterokedastisitas menggunakan uji White, dan diperoleh angka Obs*R-squared adalah 0.5723 (melebihi 0.05), maka dapat disimpulkan bahwa tidak terjadi masalah heterokedastisitas pada data. Uji normalitas dilakukan dengan metode Kolmogorov-Smirnov. Hasil pengujian pada One-Sample Kolmogorov-Smirnov Test diperoleh angka significance 0.152 yang lebih besar dari 0.05. dengan demikian, terbukti bahwa data berdistribusi normal.

Hasil pengujian regresi atas variable-variabel yang diteliti dapat dilihat pada Tabel 2 sampai dengan Tabel 4 sebagai berikut:

Tabel 2. Nilai R, R Square, SEE untuk Pengujian Hipotesis

Model Summar'

\begin{tabular}{l|r|r|r|r}
\hline Model & $\mathrm{R}$ & R Square & $\begin{array}{c}\text { Adjusted } \\
\text { R Square }\end{array}$ & $\begin{array}{r}\text { Std. Error of } \\
\text { the Estimate }\end{array}$ \\
\hline 1 & $.322^{\mathrm{a}}$ & .104 & .080 & .62579 \\
\hline
\end{tabular}

a. Predictors: (Constant), PBV, CSRI, ROE

b. Dependent Variable: CAR 
Tabel 3. Uji F dan Signifikansi untuk Pengujian Hipotesis

\begin{tabular}{|c|c|c|c|c|c|c|}
\hline \multicolumn{7}{|c|}{ ANOV Ab } \\
\hline \multicolumn{2}{|l|}{ Model } & $\begin{array}{l}\text { Sum of } \\
\text { Squares }\end{array}$ & $d f$ & Mean Square & $\mathrm{F}$ & Sig. \\
\hline 1 & Regression & 5.082 & 3 & 1.694 & 4.325 & $.006^{a}$ \\
\hline & Residual & 43.861 & 112 & .392 & & \\
\hline & Total & 48.942 & 115 & & & \\
\hline
\end{tabular}

a. Predictors: (Constant), PBV, CSRI, ROE

b. Dependent Variable: CAR

Tabel 4. Konstanta, Koefisien Regresi, T Test, dan Signifikansi

\begin{tabular}{|c|c|c|c|c|c|c|}
\hline \multicolumn{7}{|c|}{ Coefficients } \\
\hline \multirow[b]{2}{*}{ Model } & & \multicolumn{2}{|c|}{$\begin{array}{c}\text { Unstandardized } \\
\text { Coefficients }\end{array}$} & \multirow{2}{*}{$\begin{array}{c}\text { Standardized } \\
\text { Coefficients }\end{array}$} & \multirow[b]{2}{*}{$t$} & \multirow[b]{2}{*}{ Sig. } \\
\hline & & B & Std. Error & & & \\
\hline 1 & (Constant) & .096 & .160 & & .596 & .553 \\
\hline & CSRI & .898 & .385 & .205 & 2.336 & .021 \\
\hline & ROE & -.009 & .003 & -.309 & -3.285 & .001 \\
\hline & PBV & -.003 & .021 & -.015 & -.156 & .876 \\
\hline
\end{tabular}

a. Dependent Variable: CAR

Dari Tabel 2 sampai Tabel 4 di atas dapat disimpulkan bahawa: hasil uji $\mathrm{F}$ menunjukkan tingkat signifikansi 0,006 (lebih rendah dari 0.05), berarti Variabel CSRI, ROE, dan PBV secara bersama-sama memiliki pengaruh signifikan terhadap abnormal return. Hipotesis pertama $(\mathrm{H} 1)$ diterima yang ditunjukkan dari angka koefisien beta positif dan nilai sig $<0.05$. Hal ini berarti terdapat pengaruh positif yang signifikan dari pengungkapan informasi CSR terhadap abnormal return. Hipotesis kedua (H2) ditolak namun terdapat pengaruh negatif yang signifikan dari ROE terhadap abnormal return. Ditolaknya H2 karena nilai koefisien beta yang negatif. Hipotesis ketiga (H3) ditolak karena nilai beta yang negatif dan angka sig $>0.05$, yang berarti tidak terdapat pengaruh yang signifikan dari PBV terhadap abnormal return. Hasil membuktikan bahwa informasi CSR memiliki pengaruh signifikan terhadap abnormal return.

\section{ANALISA DAN PEMBAHASAN}

\section{Pengaruh Pengungkapan Informasi CSR dalam Laporan Tahunan terhadap Abnormal Return}

Hasil penelitian untuk hipotesis pertama menunjukan bahwa pengungkapan informasi CSR berpengaruh signifikan terhadap abnormal return, sehingga $\mathrm{H}_{1}$ diterima. Hasil penelitian ini mendukung dengan penelitian yang dilakukan Nuzula dan Kato (2010) terhadap perusahaanperusahaan di Jepang dan Nurdin dan Cahyandito (2006) terhadap perusahaan-perusahaan di Indonesia dimana informasi CSR yang diungkapkan perusahaan direspon baik oleh investor yang ditunjukan dengan adanya abnormal return. Pengungkapan CSR yang dilakukan perusahaan memiliki kandungan informasi, sehingga investor akan bereaksi pada pengumuman itu. Pengungkapan aktivitas perusahaan yang berkaitan dengan CSR dapat mengirimkan signal positif kepada stakeholders dan pasar mengenai prospek perusahaan dimasa yang akan datang bahwa perusahaan memberikan guarantee atas keberlangsungan hidup perusahaan dimasa yang akan datang. Hasil analisis ini mengindikasikan bahwa investor di Indonesia sudah mulai menggunakan informasi pengungkapan CSR dalam melakukan keputusan investasi. Hal ini menunjukan bahwa pasar modal Indonesia sedang mengarah atau mengikuti trend global, dimana tema-tema CSR sudah menjadi salah satu sumber pengambilan keputusan investasi bagi investor.

\section{Pengaruh Return on Equity (ROE) terhadap Abnormal Return}

Hasil penelitian untuk hipotesis kedua menujukan bahwa ROE berpengaruh terhadap abnormal return. Akan tetapi, hasil penelitian ini tidak konsisten dengan penelitian Mulyono (2008) dimana pengaruh ROE terhadap abnormal return dalam penelitian ini adalah signifikan negatif.

Perbedaan hasil penelitian ini kemungkinan disebabkan perbedaan periode penelitian, jumlah sampel, karakteristik sampel yang diteliti. Kondisi perekonomian Indonesia yang juga terkena imbas dari krisis global pada periode tahun pengamatan reaksi investor pada tahun 2008-2010. Melihat kondisi pada awal tahun 2008, dimana krisis ekonomi global melanda, tingginya tingkat inflasi global yang dapat memperlambat pertumbuhan ekonomi global sehingga akan mempengaruhi permintaan terhadap energi. Dengan semakin tingginya tingkat inflasi menyebabkan kemampuan perusahaan untuk membeli bahan baku energy seperti batubara, minyak bumi, kelapa sawit, akan berkurang. Dengan berkurangnya permintaan terhadap bahan baku energi ini, penjualan perusahaan-perusahaan yang berhubungan dengan sumber daya alam ini akan terpengaruh. Banyak perusahaan yang mengalami penurunan laba bersih yang sehingga menyebabkan ROE menurun.

Meskipun ROE yang menunjukan kemampuan perusahaaan untuk menghasilkan laba bersih mengalami penurunan, ternyata investor tetap mau melakukan investasi pada perusahaan tersebut. Lev (1989) dalam Sayekti dan Ludovicus (2007) mengatakan bahwa informasi mengenai laba digunakan oleh investor, tetapi kegunaan informasi laba tersebut bagi investor sangat 
terbatas sehingga investor juga mempertimbangkan informasi lainnya. Semakin tinggi pengungkapan suatu perusahaan, semakin kecil tingkat ketergantungan investor pada informasi laba perusahaan. Investor menilai bahwa meskipun laba saat ini mengalami penurunan namun kebutuhan akan komoditas sumber daya alam tetap diperlukan oleh siapapun sehingga memprediksikan laba dan return yang akan datang akan membaik. Apalagi sejak krisis ekonomi global pertumbuhan ekonomi Indonesia justru mengalami peningkatan. Hal ini membuat banyak investor asing yang beramai-ramai menaruh uang di Indonesia (Dampak krisis keuangan pada Indonesia tidak terlalu besar, 2008, Desember). Kepemilikan asing di Indonesia mencapai 60\% pada tahun 2008 (Bank Indonesia). Selain itu, investor-investor di Indonesia cenderung tidak panik terhadap kondisi yang sedang terjadi. Jadi, meskipun ROE perusahaan menurun, informasi ini cenderung membuat investor untuk tetap bereaksi positif yang ditunjukan dengan abnormal return.

\section{Pengaruh Price to Book Value (PBV) terhadap Abnormal Return}

Hasil penelitian untuk hipotesis ketiga menujukan bahwa tidak terdapat pengaruh positif yang signifikan dari PBV terhadap abnormal return. Hasil penelitian ini, konsisten dengan penelitian dari Sayekti dan Ludovicus (2007). Namun, hasil penelitian ini tidak konsisten dengan penelitian Dahlia dan Veronica (2008) yang menunjukan bahwa PBV berpengaruh positif terhadap abnormal return. Hal ini diperkirakan karena penilaian investor terhadap perusahaan yang memiliki PBV yang tinggi pun belum tentu akan memberikan cash return pada investor, terutama dividen. Sesuai dengan penjelasan Fransisca (2008), perusahaan yang bertumbuh umumnya akan cenderung menahan laba untuk investasi dibandingkan memberikan return berupa dividen bagi investor. Dengan demikian, meskipun perusahaan memiliki PBV yang tinggi, investor tidak memandang kemungkinan untuk mendapatkan dividen akan semakin meningkat, sehingga investor tidak menggunakan informasi PBV dalam melakukan keputusan investasinya.

\section{KESIMPULAN}

Berdasarkan hasil penelitian dan pembahasan tersebut di atas maka dapat ditarik kesimpulan sebagai berikut: (1) pengungkapan informasi CSR dalam laporan tahunan berpengaruh positif signifikan terhadap abnormal return, (2) Return on Equity (ROE) tidak berpengaruh positif signifikan terhadap abnormal return dan (3) Price to Book Value (PBV) tidak terbukti berpengaruh signifikan terhadap $a b$ normal return. Kesimpulan penelitian ini dapat di manfaatkan bagi pembuat regulasi dan perusahaan yaitu: agar perusahaan memperhatikan kelengkapan item-item pengungkapan CSR yang perlu diungkapkan dalam laporan tahunan, karena ternyata investor memperhatikan informasi tersebut dalam pengambilan keputusannya. Di samping itu juga diperlukan adanya peraturan yang lebih mengikat dari pemerintah mengenai pengungkapan CSR yang dilakukan perusahaan sehingga perusahaan dapat mengetahui lebih jelas informasi apa yang harus diungkapkan dalam laporan tahunan perusahaan.

\section{DAFTAR PUSTAKA}

Anggraini, Fr. Reni Retno. 2006. "Pengungkapan Informasi Sosial dan Faktor-Faktor yang Mempengaruhi Pengungkapan Informasi Sosial dalam Laporan Tahunan (Studi empiris pada perusahaan-perusahaan yang terdaftar di bursa efek Jakarta)". Simposium Nasional Akuntansi IX. Padang.

Brammer, Brooks, Pavelin. 2005. "Corporate social Performance and Stock Returns: UK Evidence from Disaggregate Measures" Retrieved April 21, 2011, from http://papers. ssrn.com/sol3/papers.cfm?abstract_id=739587

Dahlia dan Veronica. 2008. "Pengaruh corporate Social Responsibility Terhadap Kinerja Perusahaan (Studi empiris pada perusahaan yang terdaftar di bursa efek Indonesia pada tahun 2005 dan 2006)". Simposium Nasional Akuntansi XI. Pontianak.

Gitman, Lawrence. 2006. Principles of Managerial Finance. United States:Pearson.

ISRA. 2010, "Forum For Corporate Social Responsibility in Indonesia". Retrieved May 26, 2011, from http://www.csrindonesia.com/ editorialdetail.php?id=153

Jogiyanto. 2009. Teori Portofolio dan Analisis Investasi (edisi keenam). Yogyakarta: Yogyakarta.

Jogiyanto. 2010. Studi Peristiwa: Menguji Reaksi Pasar Modal Akibat Suatu Peristiwa (edisi pertama). Yogyakarta: Yogyakarta.

Kelana dan Chandra Wijaya. (2005). Riset Keuangan, Pengujian Empiris. Jakarta: Gramedia.

Lorraine et al. 2004. "An Analysis of Stock Market Impact of Environmental Performance Information". Accounting Forum, 28 (1), 7 26. 
Mulyono. 2008. "Hubungan Rasio Keuangan, Ukuran Perusahaan dan Arus Kas pada Laporan Keuangan Interim dan Tahunan Terhadap Abnormal Return Saham (Studi Empiris Perusahaan Manufaktur yang Terdaftar di Bursa Efek Indonesia Tahun 2002-2006)", Retrieved June 29, 2011 from http://www.skripsi4u.com/download.php?file $=38 \&$ cat $=2 \&$ subref $=0 \&$ page $=4$

Nurdin dan Cahyandito. 2006. "Pengungkapan Tema-tema Sosial dan Lingkungan", Retrieved April 21, 2011, from :http://pustaka.unpad. ac.id/wp-content/uploads/2009/06/jurnal_ klh_ penungkapan_sosiallingk_dlm_lap_tahunan faniemilia.pdf

Nuzula dan Kato. 2010. Do the Japanese Capital Markets Respond to The Publication of Corporate Social Responsibility Reports. Retrieved April 21, 2011, from http://www. wbiconpro. com/340-Nila.pdf

Sayekti, Yosefa, dan Ludovicus. 2007, Juli. 'Pengaruh CSR Disclosure Terhadap Earning Response Coefficient (Studi empiris Pada Perusahaan yang Terdaftar di Bursa efek Jakarta)". Simposium Nasional Akuntansi X. Makasar.
Scott, William. 2003. Financial Accounting Theory (4th edition). Toronto: Prentice Hall.

Scott R. Colwell, Theodore J. Noseworthy, Vitali V. Alexeev. 2010. "Market Reaction to Negative Environment Events: An Event Study of 10 Oil and Gas Companies". Retrieved April 21, 2011, from http:// valexeev.yolasite.com/resources/papers/ Events.pdf

Suwardi Eko, Kartika Hendra Titisari, dan Doddy Setiawan. 2010, Juli. "Corporate Social Responsibilty dan Kinerja Perusahaan". Simposium Nasional Akuntansi XIII. Purwokerto.

Undang-Undang Republik Indonesia No. 40 Tahun 2007 tentang Perseroan Terbatas. Retrieved February 28, 2008, from http://bapepam.go.id/reksadana/files/regulas i/UU\%2040\%202007\%20Perseroan\%20Terb atas.pdf

Utama, Sidharta.(2007). "Evaluasi Infrastruktur Pendukung Pelaporan Tanggung Jawab Sosial dan Lingkungan di Indonesia", Retrieved June 19, 2011, from http://www. csrindonesia.com/data/articlesother/2007112 1152745-a.pdf

Warta Ekonomi (Desember 2006), "Konsep Bisnis Paling Bersinar 2006: Level Adopsinya Kian Tinggi." hal 36-37. 


\section{LAMPIRAN}

\section{Lampiran 1. Corporate Social Responsibility Indeks}

\begin{aligned} \hline NO & \\ \hline & Material \\ 1 & $\begin{array}{l}\text { Persentase material bahan daur ulang yang digunakan } \\ \text { Energi }\end{array} \\ 2 &$ Energi yang berhasil dihemat berkat adanya efisiensi dan konservasi yang lebih baik \\ 3 & Inisiatif penyediaan produk dan jasa yang menggunakan energi efisien atau sumber daya terbarukan, \\ & serta pengurangan penggunaan energi sebagai dampak dari inisiatif ini. \end{aligned}

\section{INDIKATOR TENAGAKERJA}

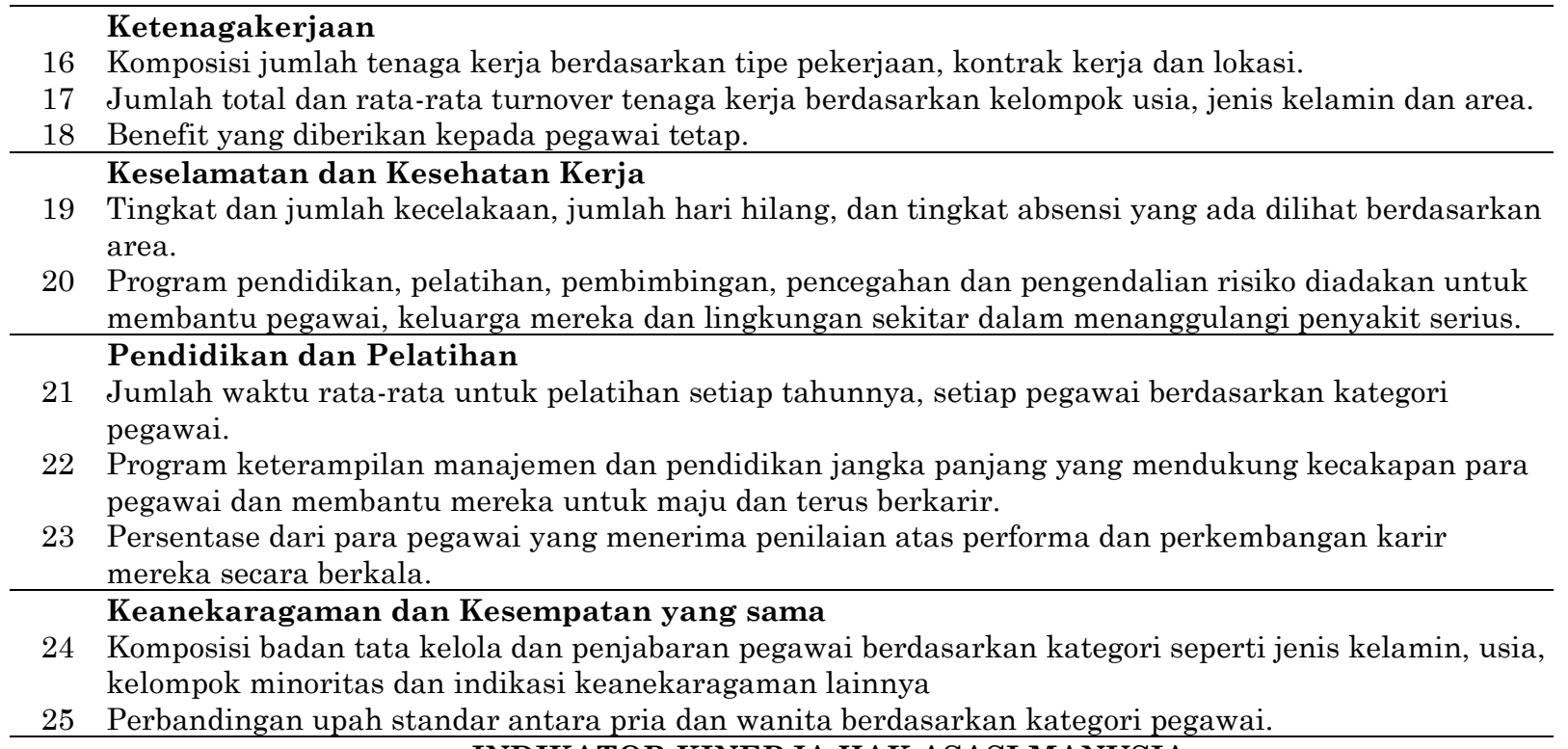
INDIKATOR KINERJA HAK ASASI MANUSIA

\section{Praktik Investasi dan Pengadaan}

26 Persentase dari mitra kerja dan pemasok yang telah melalui proses seleksi berdasarkan prinsipprinsip HAM yang telah dijalankan 


\begin{tabular}{|c|c|}
\hline NO & INDIKATOR ENVIRONMENT \\
\hline & Non-Diskriminasi \\
\hline 27 & Total jumlah kasus diskriminasi dan langkah penyelesaian masalah yang diambil \\
\hline \multirow[t]{2}{*}{28} & $\begin{array}{l}\text { Prosedur kerja yang teridentifikasi di mana hak untuk melatih kebebasan berserikat dan } \\
\text { perundingan bersama menjadi berisiko dan langkah yang diambil untuk mendukung hak kebebasan } \\
\text { berserikat tersebut }\end{array}$ \\
\hline & Tenaga Kerja Anak \\
\hline \multirow[t]{2}{*}{29} & $\begin{array}{l}\text { Prosedur kerja yang teridentifikasi memiliki risiko akan adanya pekerja anak dan langkah yang } \\
\text { diambil untuk menghapuskan pekerja anak. }\end{array}$ \\
\hline & Hak Masyarakat (Adat) \\
\hline \multirow[t]{2}{*}{30} & $\begin{array}{l}\text { Total jumlah kasus pelanggaran yang berkaitan dengan hak masyarakat adat dan langkah yang } \\
\text { diambil. }\end{array}$ \\
\hline & $\begin{array}{l}\text { INDIKATOR KINERJA KEMASYARAKATAN } \\
\end{array}$ \\
\hline
\end{tabular}

31 Sifat, cakupan, dan keefektifan atas program \& kegiatan apapun yang menilai \& mengelola dampak operasi terhadap masyarakat, termasuk saat memasuki wilayah operasi, selama beroperasi \& pasca operasi.

32 Persentase dan total jumlah unit usaha yang dianalisa memiliki risiko terkait tindak penyuapan dan korupsi.

33 Langkah yang diambil dalam mengatasi kasus tindak penyuapan dan korupsi Perilaku Anti Persaingan

34 Total jumlah tindakan hukum terhadap sikap anti kompetisi dan praktek monopoli dan kecurangankecurangan yang dihasilkan

\begin{tabular}{|c|c|}
\hline & INDIKATOR KINERJA EKONOMI \\
\hline & Kinerja Ekonomi \\
\hline 35 & $\begin{array}{l}\text { Nilai ekonomi yang dihasilkan dan didistribusikan secara langsung, termasuk pendapatan, biaya } \\
\text { operasi, kompensasi kepada karyawan, donasi dan investasi ke masyarakat, laba ditahan serta } \\
\text { pembayaran ke penyedia modal dan pemerintah. }\end{array}$ \\
\hline \multirow[t]{2}{*}{36} & $\begin{array}{l}\text { Implikasi keuangan dan berbagai risiko dan peluang untuk segala aktivitas perusahaan dalam } \\
\text { menghadapi perubahan iklim. }\end{array}$ \\
\hline & Keberadaan Pasar \\
\hline 37 & $\begin{array}{l}\text { Parameter standar upah karyawan di jenjang awal dibandingkan dengan upah karyawan minimum } \\
\text { yang berlaku pada lokasi operasi tertentu. }\end{array}$ \\
\hline 38 & $\begin{array}{l}\text { Kebijakan, penerapan dan pembagian pembelanjaan pada subkontraktor (mitra kerja) setempat yang } \\
\text { ada di berbagai lokasi operasi. }\end{array}$ \\
\hline \multirow[t]{2}{*}{30} & $\begin{array}{l}\text { Prosedur penerimaan tenaga kerja lokal dan beberapa orang di level manajemen senior yang diambil } \\
\text { dari komunitas setempat di beberapa lokasi operasi. }\end{array}$ \\
\hline & Dampak Ekonomi Tidak Langsung \\
\hline \multirow[t]{2}{*}{40} & $\begin{array}{l}\text { Pengembangan dan dampak dari investasi infrastruktur dan pelayanan yang disediakan terutama } \\
\text { bagi kepentingan publik melalui perdagangan, jasa dan pelayanan atau pun yang sifatnya pro bono. }\end{array}$ \\
\hline & INDIKATOR DAMPAK PRODUK \\
\hline 41 & $\begin{array}{l}\text { Proses dan tahapan kerja dalam mempertahankan kesehatan dan keselamatan konsumen dalam } \\
\text { penggunaan produk atau jasa yang dievaluasi untuk perbaikan dan persentase dari kategori produk } \\
\text { dan jasa yang terkait dalam prosedur tersebut. }\end{array}$ \\
\hline 42 & $\begin{array}{l}\text { Jumlah total kasus pelanggaran kebijakan dan mekanisme kepatuhan yang terkait dengan } \\
\text { kesehatan dan keselamatan konsumen dalam keseluruhan proses, diukur berdasarkan hasil } \\
\text { akhirnya }\end{array}$ \\
\hline 43 & $\begin{array}{l}\text { Praktek-praktek yang terkait dengan kepuasan konsumen, termasuk hasil survey evaluasi kepuasan } \\
\text { konsumen. }\end{array}$ \\
\hline 44 & $\begin{array}{l}\text { Program-program yang mendukung adanya standar hukum dan mekanisme kepatuhan yang terkait } \\
\text { dengan komunikasi penjualan, termasuk iklan, promosi dan bentuk kerjasama. }\end{array}$ \\
\hline 45 & Jumlah total kasus pelanggaran kebijakan dan mekanisme kepatuhan yang terkait dengan \\
\hline & $\begin{array}{l}\text { komunikasi penjualan, termasuk iklan, promosi dan bentuk kerjasama, diukur berdasarkan hasil } \\
\text { akhirnya }\end{array}$ \\
\hline
\end{tabular}

